\title{
Habitat occupancy of sloth bear Melursus ursinus in Chitwan National Park, Nepal
}

\author{
Rajan Paudel $^{1}$, Rabin Kadariya ${ }^{2}$, Babu Ram Lamichhane ${ }^{2}$, Naresh Subedi ${ }^{2}$, Mariko \\ Sashika $^{1}$, Michito Shimozuru ${ }^{1}$, and Toshio Tsubota ${ }^{1}$ \\ ${ }^{1}$ Hokkaido University \\ ${ }^{2}$ National Trust for Nature Conservation
}

September 24, 2021

\begin{abstract}
Mammals around the world face serious threats and experience massive decline in their populations and geographic ranges. The sloth bear has become extinct from two of five range countries and the existing population face serious conservation threats. Despite being endangered in Nepal, decades of conservation obliviousness have hindered their conservation and management. We assessed the distribution and habitat use by sloth bears in relation to landscape, environmental, and anthropogenic factors in Chitwan National Park, Nepal. We conducted a sign survey from March-June 2020 in $4 * 4 \mathrm{~km} 2$ grids $(\mathrm{n}=45)$ in a checkerboard approach. An observation was spatially replicated four times by recording information in four continuous search trails of $1 \mathrm{~km}$ each. We recorded presence/absence of sloth bears, termites, fruits and disturbance in the field and extracted information on tree cover, terrain ruggedness and vegetation index from remotely sensed image of the study area. The data was analyzed using single species-single season occupancy method in PRESENCE software. By using repeated observations these models account for imperfect detectability of species to provide robust estimates of species occupancy. Averaged habitat occupancy estimate obtained from the best models was $=0.53 \pm 0.04 \mathrm{SE}$ with detection probability $\mathrm{p}=0.44 \pm 0.1 \mathrm{SE}$. Selection of variable based on summed AIC weight from the top models $(\mathrm{AIC}<2)$ showed that presence of termites $(\mathrm{Wi}=0.66)$ significantly influenced sloth bear habitat occupancy. Habitat occupancy was positively influenced by termites followed by fruits, disturbance, terrain ruggedness and vegetation productivity, whereas, it was negatively influenced by tree cover. We suggest that future conservation interventions and action plans aimed at sloth bear management must adequately consider these requirements and issues.
\end{abstract}

\section{Habitat occupancy of sloth bear Melursus ursinus in Chitwan National Park, Nepal}

Rajan Prasad Paudel ${ }^{1}$, Rabin Kadariya ${ }^{2}$, Baburam Lamichhane ${ }^{2}$, Naresh Subedi², Mariko Sashika ${ }^{3}$, Michito Shimozuru ${ }^{3}$, Toshio Tsubota ${ }^{3, * *}$ Corresponding author: tsubota@vetmed.hokudai.ac.jp ${ }^{1}$ Laboratory of Wildlife Biology and Medicine, Graduate School of Veterinary Medicine, Hokkaido University, Sapporo, Japan. ${ }^{2}$ National Trust for Nature Conservation, Nepal. ${ }^{3}$ Laboratory of Wildlife Biology and Medicine, Faculty of Veterinary Medicine, Hokkaido University, Japan.

\section{Abstract:}

Mammals around the world face serious threats and experience massive decline in their populations and geographic ranges. The sloth bear has become extinct from two of five range countries and the existing population face serious conservation threats. Despite being endangered in Nepal, decades of conservation obliviousness have hindered their conservation and management. We assessed the distribution and habitat use by sloth bears in relation to landscape, environmental, and anthropogenic factors in Chitwan National Park, Nepal. We conducted a sign survey from March-June 2020 in $4^{*} 4 \mathrm{~km}^{2}$ grids $(\mathrm{n}=45)$ in a checkerboard approach. An observation was spatially replicated four times by recording information in four continuous search trails of $1 \mathrm{~km}$ each. We recorded presence/absence of sloth bears, termites, fruits and disturbance 
in the field and extracted information on tree cover, terrain ruggedness and vegetation index from remotely sensed image of the study area. The data was analyzed using single species-single season occupancy method in PRESENCE software. By using repeated observations these models account for imperfect detectability of species to provide robust estimates of species occupancy. Averaged habitat occupancy estimate obtained from the best models was $=0.53 \pm 0.04_{\mathrm{SE}}$ with detection probability $\mathrm{p}=0.44 \pm 0.1 \mathrm{SE}$. Selection of variable based on summed AIC weight from the top models $(\mathrm{AIC}<2)$ showed that presence of termites $(\mathrm{W} i$ $=0.66$ ) significantly influenced sloth bear habitat occupancy. Habitat occupancy was positively influenced by termites followed by fruits, disturbance, terrain ruggedness and vegetation productivity, whereas, it was negatively influenced by tree cover. Our results indicate that the sloth bear is an elusive, functionally unique and a potential umbrella species of the tropical ecosystems in Nepal.We suggest that future conservation interventions and action plans aimed at sloth bear management must adequately consider these requirements and issues.

\section{Keywords:}

Sloth bear, Occupancy, Nepal, Wildlife Conservation

\section{Introduction :}

Large mammals around the world face serious threats and experience massive decline in their populations and geographic ranges (Ceballos et al. 2015, 2017; Ripple et al. 2014; Karanth, 2009; Ceballos \& Ehrlich 2002). Protected areas (PAs) have become the last refuge of many threatened mammals and have contributed to conservation of some flagship species yet their effectiveness to halt decline of other sympatric species remains questioned (UNEP-WCMC \& IUCN, 2021; CBD, 2020; Li et al.2020; Geldmann et al. 2019; Schulze et al. 2018; Barnes et al. 2016; Ceballos et al. 2015; Geldmann et al. 2013; Hoffmann et al. 2010). Increasing pressure on the environment has compromised the intactness of natural habitat and species ability to procreate and persist in a healthy population (Crooks et al. 2017; Wilson et al. 2016). Extinction risk of mammals in small, degraded, and isolated habitats increase in long run through population decline and loss of genetic diversity (Frankham et al. 2002, 2010).

The sloth bear Melursus ursinus is an endemic mammal of the Indian sub-continent occurring in a wide range of habitats including dry or moist forest, savannah, scrublands and grasslands (Dhariya et al. 2020; Garshelis et al.1998). However, their populations have declined by almost $50 \%$ over the last three decades and are categorized as "vulnerable" in IUCN Red List (Dhariya et al. 2020). They have become extinct from entire country in Bangladesh (Islam et al.2013) and possibly from Bhutan and locally from different habitat patches of India and Nepal (Dhariya et al. 2020; Garshelis et al 1998). They were once present along continuous strip of forest and grasslands in the southern Nepal until 1950s when expansion of human settlement and agriculture confined them primarily in few protected areas (Amin et al. 2018; Jnawali et al. 2011). While distribution, habitat use, population and conservation ecology of sympatric co-predators' tiger and leopard is well explored (Subedi et al. 2021; Thapa et al 2021; Lamichhane et al. 2019; 2017; Dhungana et al. 2019, 2018; Kafley et al. 2019; Pokheral et al. 2019; Karki et al. 2015; Barber-Meyer et al. 2013; Bhattarai et al. 2012; Carter et al.2012; Smith 1984), similar studies for sloth bears are limited (Lamichhane et al. 2016; Laurie \& Seidensticker, 1977; Garshelis et al. 1999; Joshi et al. 1995,1997,1999) to from a conclusive view on its current conservation status.

Information on the species spatial distribution pattern in the wild and factors that influence this pattern are critical for setting conservation priorities and site-specific management actions for securing these population over time. Primarily, species distribution and habitat use are determined by the availability and spatial variation of food resources and the extent of natural and anthropogenic threats (Ceballos \& Ehrlich, 2002; Schipper et al. 2008). Unlike other carnivores, bears exhibit a different set of morphological specializations for diet (Sacco et al. 2004). Sloth bears are specially adapted for myrmecophagy with the composition of diet varying with temporal and spatial availability of the food resources particularly termites and fruits (Philip et al.2021; Palei et.al. 2014, 2020; Rather et.al. 2020; Mewada et al. 2019,2015; Baskaran et al.2015; Khanal \& Thapa, 2014; Sukhadiya et al. 2013; Baskaran \& Desai.2010; Bargali et.al. 2004; Joshi et.al,1997; 
Laurie \& Seidensticker,1977). In fruit rich areas, sloth bears play important role in the dispersal of seed and regeneration of fruit plants (Sreekumar \& Balakrishnan, 2002) thus playing important role in maintenance of forest structure and composition. They largely prefer habitats away from human disturbance (Joshi et al. 1999; Babu et.al 2015, Ghimire \& Thapa,2014; Ratnayeke et.al.2007) but they have also been reported to tolerate some degree of disturbance in human-dominated landscapes (Puri et.al 2015, Bargali et al. 2012; Akhtar et al.2004, 2007). Prevalence of human-sloth bear conflict in India (Rajpurohit \& Kruasman, 2000; Debata et al. 2012,2017; Garcia et al. 2016; Dhamorikar et al. 2017; Bargali et al. 2005; Ratnayeke et al 2014; Ahmed et al.2012; Sharp et al.2020; Ketting et al.2020) and Nepal (Pokharel et al. 2020; Ruda et al. 2020; Silwal et al. 2019; Lamichhane et al. 2018; Acharya et al.2016) is one of the threats to its survival. Additionally, removal of the individuals through poaching or live capture for use as 'dancing bears' is not common but can be detrimental enough for a population that is already small, isolated and threatened.

Direct observation of sloth bears is difficult because of their rare, elusive, and aggressive nature. We use occupancy analysis which is widely used in recent years and have evolved as a strong, flexible, and viable method for estimating species distribution and occupancy dynamics while accounting for possible non-detection as well as incorporating predictor variables measured remotely or during the observation process in field (MacKenzie et al.2002,2003, 2004, 2017; Bailey et al. 2014; MacKenzie \& Nichols 2004; MacKenzie \& Royle, 2005). We employed single-season occupancy model for understanding the distribution and occupancy dynamics of the sloth bears and its ecological, environmental, and anthropogenic determinants.

\section{METHODOLOGY}

Study Area: The study was conducted in Chitwan National Park $\left(27^{\circ} 16.56\right.$ '- $27^{\circ} 42.14^{\prime} \mathrm{N}, 8^{\circ} 50.23^{\prime}-$ $\left.84^{\circ} 46.25^{\prime} \mathrm{E}\right)$, the first national park situated in south central Nepal covering $953 \mathrm{sq} . \mathrm{km}$. It is a designated Ramsar site and UNESCO world heritage site. The park landscape consists of alluvial plain and mountain range of the outer Himalaya known as Churiya hills. Seasonal and perennial rivers originate in the Churiya and cascade down to the lowlands before being drained by three major river systems. The East Rapti River runs along the northern boundary of park, Reu river runs along the southern boundary of the park, both the rivers mix before being drained to the Ganges by the Narayani river that forms the western boundary of the park. In the east, the park is contagious with the boundary of Parsa National Park. The study area lies in the Indomalaya biogeographic realm and consists of tropical moist forest vegetation dominated by deciduous forest of Shorea robusta (70\%) followed by grassland (10\%), riverine forest (7\%), mixed forest (7\%) and wetlands (4\%). The successional gradient of the park is formed of ten grasslands and three forest associations (Lehmkuhl J.F.1999). The area has hot and humid summer monsoon from mid-May to late-September when $90 \%$ of the $2,400 \mathrm{~mm}$ of rain falls. The monsoon causes dramatic floods which alter the courses and character of the rivers and thus plays important role in shaping park's landscape particularly creating and maintaining different successional stages of habitats. Temperatures reach a maximum of 38degC during wet summer and drop to a minimum of $6 \operatorname{deg} \mathrm{C}$ in dry winter. The matrix of different habitat conditions and climate makes this area a hotspot of biodiversity harbouring the largest population of rhinos, tigers and sloth bears and many other threatened flora and fauna in Nepal. The core park area is surrounded by a $750 \mathrm{sq} . \mathrm{km}$ buffer zone, which consists of forests, settlements and agriculture lands. The park and the local people jointly initiate community development activities and manage natural resources in the buffer zone. Thirty-to-fifty percent of the park revenue particularly from tourism activities is provided to these buffer zone communities for community development and natural resource management activities. The buffer zone community is socially mixed of indigenous fishing community and immigrated hill communities relying mostly on subsistence agriculture.

Survey Design: We overlaid grids of $4 * 4 \mathrm{~km}$ over the map of study area (Figure 1). With a random start we surveyed in grids at a systematic spacing of $4 \mathrm{~km}$. This checkerboard sampling design minimizes autocorrelation between sampling grids, facilitates concentration of survey efforts, even coverage of large and hostile study area and is suitable for studying medium to large mammals with relatively ease. It has been used to study elephants (Thapa et al. 2019), tigers (Thapa \& Kelly, 2017) and antelope (Krishna et al. 2008). This resulted in a total of 45 grids which covered 720 sq.km ( $43 \%$ coverage of park area). 
Our grid size is comparable to the home range of sloth bears which is estimated as 9 and 14 sq.km for male and female sloth bears respectively (Joshi et.al 1995). Studies on sloth bears in India have shown that the spatial replicates produce occupancy estimates similar to the temporal replicates and thus are useful for distribution assessments of species when field resources are limited or logistic challenges preclude traditional survey approaches that yield temporally replicated data (Srivathsa et al.2017). We used four spatial replicates of one $\mathrm{km}$ length in each grid.

Field Methods: We carried out sign surveys within the selected 45 grids with a sampling effort of four $\mathrm{km}$ in each grid. Two observers walked in the grid and recorded both direct sightings and indirect signs such as scat and footprint found within the visible width of the search trail. We divided this search trails or replicates into equal distanced segments of $200 \mathrm{~m}$. A segment was recorded as occupied ' 1 ' if we made a direct visual sighting or if we detected the footprint or scat of sloth bears. Sloth bears are often found to defecate in open areas along the road, over the bridges and on the 'machans' wildlife view towers and other exposed surfaces. Absence of black bears, sun bears or other species of similar size and habit in the study area enabled us in unambiguous identification of the sloth bear signs in the field. To standardize the detection process, avoid biases that may arise from misidentification and decay of signs and adhere to the closure assumption in occupancy studies, we only included fresh sloth bear signs - direct sighting, footprints, and scat along sample trails ( Putman R.J. 1984; Morin et al.2016; Rota et al. 2009; Laing et al. 2003). Field surveys were carried out between March and June of 2020. Within the segments, we collected sloth bear presence/absence data and associated ecological, environmental and anthropogenic variables. When the signs and covariates were detected in the segment it was recorded as ' 1 ' and ' 0 ' otherwise. If the sampling could not be done because of logistic reasons, outside park jurisdiction or under intense human use, the segment was treated as a missing observation.

\section{Co-variate Selection:}

We selected a mix of six plausible remotely sensed and ground-based variables that reflected characteristics of landscape, condition of habitat, persistent anthropogenic pressures, and availability of major food resources based on the review of available literature. For small study area with few sample sites model loses power of explanation and unwanted errors increase as the number of variables are increased in a model. It is generally advised to use one variable per ten sites in occupancy model. Thus, following the principles of parsimony, we included three site co-variates and three sample covariates (See Table $\mathbf{1}$ ). We selected termites, fruits and disturbance as sample covariates and measured them in the field. Tree cover, terrain ruggedness index (TRI) and enhanced vegetation index (EVI) were site level covariates that were obtained from remotely sensed images. Termites and fruits were selected as variables as they represent the dominant food resource for sloth bears (Khanal \& Thapa, 2014; Sukhadiya et al. 2013; Bargali et al. 2012; Joshi et al.1997). Studies in India have shown that sloth bears were positively associated with the topographic ruggedness (Puri et al. 2015; Srivathsa et al. 2017) and forest cover (Srivathsa et.al. 2017). Sloth bears have been reported to avoid human and livestock disturbance (Babu et al. 2015; Puri et al. 2015) but they have also been reported from human dominated landscapes with degraded habitats (Bargali et al. 2012). We combined human disturbance, livestock disturbance and fire in our search trails as a measure of disturbance. They are thought to prefer relatively dry habitats as indicated by the negative relationship between habitat occupancy and vegetation productivity (Srivathsa et al. 2017). We chose EVI rather than normalized difference vegetation index (NDVI) to measure vegetation productivity in our study as EVI has improved sensitivity. In Nepal, it was found that sloth bears move to grasslands during the dry season and prefer to remain in forests during the wet season (Joshi et al. 1995). We used the tree cover data prepared by Hansen et al (2013) as a proxy of habitat condition, higher cover indicating forested habitat and lower cover indicating grassland habitat. Covariates were first checked for collinearity (Figure 2), and then z transformed before running occupancy models (Kirshna et al. 2008; Panthi et al. 2017). We hypothesized that ceteris paribus 1) sloth bear occupancy will increase with increasing termites, fruits and heterogeneity in the terrain and, 2) sloth bear occupancy will decrease with increasing tree cover, EVI and disturbance.

Occupancy estimation and modelling the effects of covariates: 
Studies have demonstrated that spatial replication can serve as a good surrogate for temporal replication in occupancy studies of sloth bears (Srivathsa et.al.2017). For our grids we considered $1 \mathrm{~km}$ search trail as one spatial replicate. We employed an equal search effort of $4 \mathrm{~km}$ in each grid, thus maintaining four spatial replicates in each grid. Detection histories were constructed for each grid, where ' 1 ' indicates detection of species and ' 0 ' indicates non-detection and ' ' indicates a missing observation. For example a detection history of '010-' indicates that the sloth bear or its sign was not detected in first and third search trail, detected in the second search trail and the sampling was not done in the fourth search trail. For each covariate, data recorded in each segment along the search trail were pooled to obtain an single average covariate score. We ran single-species single season occupancy analysis using a maximum likelihood-based approach in the PRESENCE software 2.12.31to derive calculated occupancy (Hines, 2006). We followed a two-step process to estimate probability of detection and probability of bear occurrence. First, we modelled detection (p) keeping constant structure for occupancy model as $\psi($.$) . We hypothesized that three ground$ based covariates 1) Termite 2) Fruit and 3) Disturbance Index would affect our probability of detecting sloth bears and its signs along the search trail, so we used them in the first step for modelling detection probability. We hypothesized that sloth bear signs detection will be higher in areas with termite mounds and fruits and they will be lower in areas with high disturbance. We modelled different combinations of the detectability (p) covariates and selected the best model based on minimum AIC, keeping the $\psi$ fixed.

In the second step, we modelled probability of occupancy $(\psi)$ keeping the top detection model from step one as a constant structure for detection model (Srivathsa et al. 2017; Panthi et al. 2017; Doherty et al. 2012). We constructed a set of 27 priori candidate models, each representing a different ecological hypothesis. These models included either single or additive effects of two or more covariates to investigate the influence of covariates on occurrence. Model fit was assessed using the parametric bootstrap procedure (MacKenzie \& Bailey, 2004). The covariate models were compared and ranked using an information theoretic approach, relying on Akaike Information Criterion (AIC) for testing relative model fits. Models with $\Delta$ AIC of $<2$ were strongly supported by the data. Due to inherent advantage of model averaging (Burnham \& Anderson, 1998), the final occupancy estimates and associated standard error were averaged across the model set. To infer relative influence of covariates on occurrence, we summed the computed model weights of all the model containing the particular covariate. Additionally, we used the estimated $\beta$-coefficients to assess the strength of association of each covariate with occupancy probability.

\section{RESULTS:}

\section{Occupancy and Detection:}

The estimated sloth bear detection probability was $0.44 \pm 0.1_{\mathrm{SE}}$. The top model with lowest AIC value that influenced detection probability included termites, fruits and disturbance(Table 2). Among them, termite was the most influential covariate that had significant effect on detection probability $\left(\mathrm{W}_{i}=0.81, \beta=1.80 \pm\right.$ $0.53_{\mathrm{SE}}$ ) of sloth bears. We used this top model for detectability in subsequent analyses to model occupancy probability. Occupancy results are presented in Table 3 . Among the set of candidate occupancy models, the model including termites $\left(\beta \mathrm{T}=0.80 \pm 0.40_{\mathrm{SE}}, \mathrm{W} i=0.12\right)$ and fruits $\left(\beta \mathrm{F}=0.58 \pm 0.42_{\mathrm{SE}}, \mathrm{W} i=0.12\right)$ was the best occupancy model. Since, a single model did not fully explain the observed data and because of the inherent advantages of model averaging (Burnham \& Anderson,1998) we obtained average occupancy estimates, and the associated standard errors from the most competitive models $(\Delta \mathrm{AIC}<2)$. The model averaged occupancy estimate for our study area was $0.53 \pm 0.04_{\mathrm{SE}}$.

\section{Influence of Covariates:}

The null model that did not include any covariates for detection or occupancy performed poorly and ranked the lowest ( $\mathrm{AIC}=175.48)$. Model performance improved after we included the covariates alone or in combination according to our priori hypothesis. Summed AIC weight of covariates from the most competitive models was highest for termite followed by fruit, disturbance, tree cover and equal for EVI W $i=0.12$ and TRI (Figure 3). Average model specific $\beta$-coefficient value from the top competitive models for termites, fruit, disturbance, terrain ruggedness and vegetation productivity indicated their positive influence on sloth 
bear occupancy whereas negative beta coefficient for tree cover indicated its negative association with sloth bear habitat occupancy (Figure 4) .

\section{Discussion:}

\section{Occupancy and Detection:}

This study provides the first ever occupancy estimate for sloth bears from Nepal. Sloth bears were elusive species with less than a half $(\mathrm{p}=0.44)$ probability of detection. Their signs were detected in 21 out of the sampled 45 grids, giving a naïve occupancy of 0.46 . By explicitly incorporating the imperfect detection of animals into the occupancy estimate, the proportion of area occupied by sloth bear in Chitwan national park substantially increased $(=0.53)$. An increase in habitat occupancy by $15 \%$ over the naïve estimate highlights the importance of considering the imperfect detection when studying sloth bears.

Our estimates are comparable to earlier studies on sloth bears outside Nepal (See Table 4). Habitat occupancy estimates for the sloth bear have varied between 0.54 to 0.83 in India. This difference might be because of difference in the home range of the species. The home range for sloth bears in Nepal is estimated at 9-14 sq.km in Chitwan (Joshi et al .1995) which is lower than in India estimated at $12 \mathrm{sq.} \mathrm{km} \mathrm{for} \mathrm{a} \mathrm{female} \mathrm{and}$ $85 \mathrm{sq}$. km for a male (Yoganand et al. 2005) and higher than that estimated for sub-species Melursus ursinus ornatus at 2.2 and 3.8 sq.km in Srilanka (Ratnayeke et al. 2007, 2021) respectively for female and male sloth bears. Additionally, most of the reported studies of sloth bear occupancy in India are from the Western ghats that has one of the largest blocks of contiguous forest cover and diversity of habitat conditions consisting of semi-evergreen, tropical moist, dry deciduous, thorny forest and scrub interspersed with agricultural area and rocky outcrops while our study area is relatively homogenous with small grasslands patches interspersed in a deciduous forest habitat. The occupancy-abundance relationship of species tends to be linked (Gaston et al. 2002; Zukerberg et al. 2008) particularly at the small and homogenous areas (Hui et al. 2009). Considering our occupancy estimate of 0.53 obtained from our sampling of the study area, the suitable habitat inside the park is $\sim 500$ sq.km and the population around $\sim 100-150$ individuals. It indicates that sloth bears have fairly wide distribution throughout the park, with relatively higher occupancy (psi $>0.53$ ) areas along the northern boundary of the park (Figure 5) . Both Laurie \& Seidensticker (1977) and Garshelis et al (1999) recognize that there is uneven distribution of sloth bears with high density in the alluvial floodplains along the bank of Rapti river in north part of the park and relatively lower density on rest of the park dominated by upland Sal forest.

\section{Influence of Covariates:}

Summed AIC weight from the most competitive $(\Delta \mathrm{AIC}<2)$ eight models showed that termites are most important covariates followed by fruit, disturbance, tree cover, TRI and EVI (Figure 2) . The averaged strength of positive influence of covariates in habitat occupancy was higher for termites followed by fruit, disturbance, TRI and EVI while it was negative for tree cover. The $95 \%$ confidence interval (CI) of averaged beta coefficients occupancy covariates overlapped zero except for termites indicating high confidence on the magnitude and direction of influence by termites but less confidence on similar influence by other variables (Figure 3) .

Food resources of sloth bears particularly termites followed by fruits had relatively strong influence on sloth bear occupancy. This is expected because sloth bears are opportunistic omnivores specialized for myrmecophagous diet particularly termites. Studies on feeding ecology also shows that termites are most frequent in diet throughout year while fruits dominate according to seasonal availability (Yoganand et al. 2005; Palei et al. 2014, 2020; Bargali et al.2004; Ramesh et al. 2012; Rather et al. 2020; Philip et al. 2021). In Chitwan, fruits are available for short duration from April-August while termites increasingly dominate the sloth bear's occurring in $52 \%$ of scats in 1970s (Laurie and Seidensticker, 1977), $81 \%$ during 1990s (Joshi et. al 1997) and 92\% in 2010s (Khanal and Thapa 2014). Sloth bears had negative association with tree cover indicating its preference for open grassland habitat. During the dry season, the soil in upland Sal forest habitat becomes stiff (Mall \& Karki, 2016) and termites excavate deeper into the ground to keep up with lowering water table (Mugendi D.G 2020; Ahmed et al. 2018; Kalumanga, 2016; Dangerfield 
et.al.1998). While water table is relatively higher in alluvium grasslands and the soil is relatively loose making it favourable for sloth bears to obtain termites. Correlation analysis with tree cover indicated that not termites mounds $(\mathrm{r}=0.02)$ but fruits were more abundant in grasslands $(\mathrm{r}=-0.28)$ during this period. Axelsson and Andersson E.P. 2012 and Chakraborty and Singh 2020 also observed that termite mounds were higher in forested areas compared to edge or open habitats. However, Garshelis et al (1999) also showed that mound digging by sloth bears was higher in grasslands despite high density of mounds in the forest. They also reported high ratio of diggings to obtain underground colonies of termites during the dry season. Thus, the preference for habitats with open tree cover during the dry season may be due to the better accessibility of food resources.

We expected that disturbance would have negative influence on habitat occupancy by sloth bears but in contrast the averaged beta coefficient for the covariate indicated otherwise. Understanding effects and impact of disturbance on species is challenging as it is driven by multiple factors such as individual behavior, evolutionary history as well as the frequency, duration and scale of disturbance events (Graham et al.2021; Iwasaki \& Noda, 2018; Sousa W.P. 1984). In relatively intact landscape such as in western ghats, India, sloth bears have shown to avoid disturbance (Das et al. 2014; Puri et al. 2015; Babu et al. 2015) while in human dominated landscapes they have been reported to tolerate some degree of disturbance (Bargali et al. 2012) often consuming cultivated crops (Palei et al. 2019), human food waste (Prajapati et al. 2021) and causing conflicts with humans (Debata et al. 2017; Dhamorikar et al. 2017). Human-sloth bear conflict is common throughout the year in chitwan national park suggesting that sloth bears perceive humans as threats (Acharya et al.2016; Silwal et al.2016; Lamichhane et al. 2018). However, sloth bears might be using disturbed habitat in moderation for requirements such as food, water and shelter as suggested by weak but positive correlation of disturbance with terrain ruggedness, vegetation productivity and termites (Figure 2). Rugged terrain provides sloth bears with resting and denning refuge (Baskaran et al. 2015; Bargali et al. 2012; Akhtar et al. 2007) sites and cover to hide their cubs from potential predators like tigers. We used coefficient of variation in terrain ruggedness and enhanced vegetation productivity across our grids as it better represented the heterogeneity in the habitat. They were positively related but did not have enough variation to produce significant effect on the sloth bear occupancy. The weak association of covariate might be because our study was more localized while these variables are more adequately captured at a larger scale (Rather et al. 2021; Srivathsa et al. 2017).

\section{Conservation Implications}

We show that sloth bears are widespread but elusive in CNP whose detection and occupancy is influenced by a range of variables. Landscape features like ruggedness change over decades, however, habitat variables like tree cover, vegetation productivity as well as the availability of fruits and insects change over short time periods. While generalist species may adapt to such changes, specific feeding and habitat requirements of sloth bears make it more vulnerable. Changes particularly loss and fragmentation of habitat can have longterm genetic consequences through loss of genetic diversity and population decline (Murphy et al.2017; Thatte et al. 2020; Dutta et al. 2015). Furthermore, studies have shown decline of sympatric carnivores where conservation are focused on revival of single species such as tigers (Jhala et al. 2020; Li et al. 2020). Tigers and sloth bear co-occur in Nepal where the former's population has almost doubled since 2009 (DNPWC \&DFSC, 2018) Direct threats on its population through predation by tigers (Joshi et al. 1999) might be low, however indirect consequences of habitat alteration due to tiger focused management can be expected. Grassland habitat in the park is shrinking due to proliferation of shrub, woody vegetation as well as invasive alien plants which is already impacting grassland dependent species (Subedi et al. 2017; Murphy et al. 2013). Intactness of the habitat and species' abilities to survive and reproduce is further challenged by anthropogenic pressure which is exacerbated by the increasing impacts of climate changes (Pant et al. 2020). The fate of this unique ursid, therefore, not only relies on how it responds to the changing availability of insects, fruits and habitat but also on how park managers respond through management actions/inactions. Our study can serve as a general guidance to parks and wildlife conservation authorities towards departure from incidental conservation to active management of sloth bear population. Management actions should be geared towards creation of suitable habitat such as through creation of habitat mosaics with grasslands and patches of wild 
fruits that enable sloth bears to access their main food throughout the year and successfully reproduce. We suggest empirical multi-season assessments of disturbance intensity and relative cost and benefits that these disturbed and undisturbed habitats might provide for sloth bears to enhance our understanding of sloth bear distribution and habitat use. Furthermore, investigations on abundance of sloth bear as well as ground dwelling and mound building termites, fruit trees and other insects is required for a deeper understanding of ecological interactions and behavioural responses of the sloth bear. Our findings when combined with future knowledge generated from long-term experimental research and monitoring of sloth bear can serve as a valuable baseline for formulation of sloth bear conservation strategy and management plan.

\section{Declaration:}

Funding: International Association for Bear Research and Management, National Geographic Society (EC59498R-19), Rufford Foundation (29046-1); Cleveland Metroparks Zoo; The Mitsui \& Co. Environment Fund; Hokkaido University (WISE Program)

Conflicts of interest: No conflict of interest

Ethics approval: Not applicable

Consent to participants: Not applicable

Data Accessibility : The data used to generate analysis is presented in the table and appendices and will be archived in publicly accessible repository Dryad.

Authour's Contribution: RPP, RK, NS conceptualized the research; RPP lead the data collection, curation, formal analysis and wrote the original draft; RK supported analysis, funding acquisition, writing-review and editing; BRL supported in formal analysis, methodology, writing-review and editing, MSh supported writing-review and editing; TT supervised the study (lead); NS, MSh, MS supervised the study (Equal).

\section{Acknowledgements}

We like to thank the Department of National Park and Wildlife Conservation for providing research permission to conduct this study. We thank Haribhadra Acharya, Hem Raj Acharya, Madhuri Karki, Gopal Bhandari and Lokendra Adhikari for facilitating this process. We highly acknowledge the support provided by National Trust for Nature Conservation and their staff at Biodiversity Conservation Center, Sauraha. We want to thank Ramkumar Aryal, Raju Chaudhary, Harkaman Lama,Tikaram Tharu, Munna Chaudhary, Pooja Basnet, Bachche Pajiyar, Tirtha Lama, Surendra, Binod, Ramesh and Ganesh for their assistance in the field work.

\section{References}

1. Acharya KP, Paudel PK, Neupane PR, Köhl M (2016) Human-Wildlife Conflicts in Nepal: Patterns of Human Fatalities and Injuries Caused by Large Mammals. PLoS ONE 11(9): e0161717. https://doi.org/10.1371/journal.pone.0161717

2. Ahmed, J.B. and Pradhan, B., 2018. Termite mounds as bio-indicators of groundwater: Prospects and constraints. Pertanika Journal of Science and Technology .

3. Ahmed, R.A., Prusty, K., Jena, J., Dave, C., Das, S.K., Sahu, H.K. and Rout, S.D., 2012. Prevailing human carnivore conflict in Kanha-Achanakmar corridor, Central India. World Journal of Zoology , 7 (2), pp.158-164.

4. Akhtar, N., Bargali, H.S. and Chauhan, N.P.S., 2004. Sloth bear habitat use in disturbed and unprotected areas of Madhya Pradesh, India. Ursus, pp.203-211.

5. Akhtar, N., Bargali, H.S. and Chauhan, N.P.S., 2007. Characteristics of sloth bear day dens and use in disturbed and unprotected habitat of North Bilaspur Forest Division, Chhattisgarh, central India. Ursus , pp.203-208.

6. Amin, R., H. S. Baral, B.R. Lamichhane, L.P. Poudyal, S. Lee, S.R. Jnawali, K.P. Acharya, G.P. Upadhyaya, M.B. Pandey, R. Shrestha, D. Joshi, J. Griffiths, A.P. Khatiwada \& N. 
Subedi (2018). The status of Nepal's mammals. Journal of Threatened Taxa 10(3): 1136111378; http://doi.org/10.11609/jott.3712.10.3.11361-11378

7. Axelsson, E.P. and Andersson 2012. A case study of termite mound occurrence in relation to forest edges and canopy cover within the Barandabhar forest corridor in Nepal. International Journal of Biodiversity and Conservation , 4 (15), pp.633-641.

8. Babu, S., Karthik, T., Srinivas, G. and Kumara, H.N., 2015. Linking critical patches of sloth bear Melursus ursinus for their conservation in Meghamalai hills, Western Ghats, India. Current Science, pp.1492-1498.

9. Bailey, L.L., MacKenzie, D.I. and Nichols, J.D., 2014. Advances and applications of occupancy models. Methods in Ecology and Evolution , 5 (12), pp.1269-1279.

10. Barber-Meyer, S.M., Jnawali, S.R., Karki, J.B., Khanal, P., Lohani, S., Long, B., MacKenzie, D.I., Pandav, B., Pradhan, N.M.B., Shrestha, R. and Subedi, N., 2013. Influence of prey depletion and human disturbance on tiger occupancy in N epal. Journal of Zoology, 289 (1), pp.10-18.

11. Bargali, H.S., Akhtar, N. and Chauhan, N.P.S., 2004. Feeding ecology of sloth bears in a disturbed area in central India. Ursus, 15 (2), pp.212-217.

12. Bargali, H.S., Akhtar, N. and Chauhan, N.P.S., 2005. Characteristics of sloth bear attacks and human casualties in North Bilaspur Forest Division, Chhattisgarh, India. Ursus , pp.263-267.

13. Bargali, H.S., Akhtar, N. and Chauhan, N.P.S., 2012. The sloth bear activity and movement in highly fragmented and disturbed habitat in central India. World Journal of Zoology, 7 (4), pp.312-319.

14. Barnes, M., Craigie, I., Harrison, L. et al. Wildlife population trends in protected areas predicted by national socio-economic metrics and body size. Nat Commun 7, 12747 (2016). https://doi.org/10.1038/ncomms12747

15. Baskaran, N. and Desai, A.A., 2010. Does indigestible food remains in the scats of Sloth Bear Melursus ursinus (Carnivora: Ursidae) represent actual contribution of various diet items?. Journal of Threatened Taxa, pp.1387-1389.

16. Baskaran, N., Venkatesh, S., Srivasthava, S.K. and Desai, A.A., 2015. On the Behavioural Ecology of Sloth Bear (Melursus ursinus Shaw 1791) in Mudumalai Wildlife Sanctuary, Western Ghats, India. Animal diversity, natural history and conservation , 5 , pp.313-333.

17. Bhattarai, B.P. and Kindlmann, P., 2012. Habitat heterogeneity as the key determinant of the abundance and habitat preference of prey species of tiger in the Chitwan National Park, Nepal. Acta Theriologica, 57 (1), pp.89-97.

18. Burnham, K.P. and Anderson, D.R., 1998. Practical use of the information-theoretic approach. In Model selection and inference (pp. 75-117). Springer, New York, NY.

19. Carter, N.H., Shrestha, B.K., Karki, J.B., Pradhan, N.M.B. and Liu, J., 2012. Coexistence between wildlife and humans at fine spatial scales. Proceedings of the National Academy of Sciences , 109 (38), pp.15360-15365.

20. Ceballos, G. and Ehrlich, P.R., 2002. Mammal population losses and the extinction crisis. Science , 296 (5569), pp.904-907.

21. Ceballos, G., Ehrlich, P.R. and Dirzo, R., 2017. Biological annihilation via the ongoing sixth mass extinction signaled by vertebrate population losses and declines. Proceedings of the national academy of sciences , 114 (30), pp. E6089-E6096.

22. Ceballos, G., Ehrlich, P.R., Barnosky, A.D., Garcia, A., Pringle, R.M. and Palmer, T.M., 2015. Accelerated modern human-induced species losses: Entering the sixth mass extinction. Science advances , 1 (5), p.e1400253.

23. Convention on Biological Diversity (2020) Global Biodiversity Outlook 5 - Summary for Policy Makers. Montreal.

24. Crooks, K.R., Burdett, C.L., Theobald, D.M., King, S.R., Di Marco, M., Rondinini, C. and Boitani, L., 2017. Quantification of habitat fragmentation reveals extinction risk in terrestrial mammals. Proceedings of the national Academy of Sciences , 114 (29), pp.7635-7640.

25. Dangerfield, J.M., McCarthy, T.S. and Ellery, W.N., 1998. The mound-building termite Macrotermes michaelseni as an ecosystem engineer. Journal of tropical Ecology , 14 (4), pp.507-520. 
26. Das, S., Dutta, S., Sen, S., Jijumon, A. S., Babu, S., Kumara, H. N., \& Singh, M. (2014). Identifying regions for conservation of sloth bears through occupancy modelling in north-eastern Karnataka, India. Urus, 25(2), 111-120. https://doi.org/10.2192/URSUS-D-14-00008.1

27. Debata, S., Sahu, H.K. and Swain, K.K., 2012, November. Human-Sloth bear conflict in Balasore Wildlife Division, Odisha, India. In Book of Abstracts of 21st International Conference on Bear Research and Management 26-30 November 2012, New Delhi, India (p. 164).

28. Debata, S., Swain, K.K., Sahu, H.K. and Palei, H.S., 2017. Human-sloth bear conflict in a humandominated landscape of northern Odisha, India. Ursus, 27 (2), pp.90-98.

29. Dhamorikar, A.H., Mehta, P., Bargali, H. and Gore, K., 2017. Characteristics of human-sloth bear (Melursus ursinus) encounters and the resulting human casualties in the Kanha-Pench corridor, Madhya Pradesh, India. Plos one, 12 (4), p.e0176612.

30. Dharaiya, N., Bargali, H.S. \& Sharp, T. 2020. Melursus ursinus (amended version of 2016 assessment). The IUCN Red List of Threatened Species 2020: e.T13143A166519315. https://dx.doi.org/10.2305/IUCN.UK.20201.RLTS.T13143A166519315.en. Downloaded on 13 July 2021.

31. Dhungana, R., Lamichhane, B.R., Savini, T., Dhakal, M., Poudel, B.S. and Karki, J.B., 2019. Livestock depredation by leopards around Chitwan National Park, Nepal. Mammalian Biology, 96 (1), pp.7-13.

32. Dhungana, R., Savini, T.O.M.M.A.S.O., Karki, J.B., Dhakal, M., Lamichhane, B.R. and Bumrungsri, S., 2018. Living with tigers Panthera tigris: patterns, correlates, and contexts of human-tiger conflict in Chitwan National Park, Nepal. Oryx , 52 (1), pp.55-65.

33. DNPWC and DFSC. (2018). Status of Tigers and Prey in Nepal. Department of National Parks and Wildlife Conservation \& Department of Forests and Soil Conservation. Ministry of Forests and Environment, Kathmandu, Nepal.

34. Doherty, P.F., White, G.C. and Burnham, K.P., 2012. Comparison of model building and selection strategies. Journal of Ornithology, 152 (2), pp.317-323.

35. Dutta, T., Sharma, S., Maldonado, J. E., Panwar, H. S., \& Seidensticker, J. (2015). Genetic Variation, Structure, and Gene Flow in a Sloth Bear ( Melursus ursinus ) Meta- Population in the Satpura-Maikal Landscape of Central India. PLOS One, 1, 1-16. https://doi.org/10.1371/journal.pone.0123384

36. Dutta, T., Sharma, S., Maldonado, J.E., Panwar, H.S. and Seidensticker, J., 2015. Genetic variation, structure, and gene flow in a sloth bear (Melursus ursinus) meta-population in the Satpura-Maikal landscape of Central India. PLoS One, 10(5), p.e0123384.

37. Frankham, R., 2010. Where are we in conservation genetics and where do we need to go?. Conservation Genetics , 11 (2), pp.661-663.

38. Frankham, R., Ballou, S.E.J.D., Briscoe, D.A. and Ballou, J.D., 2002. Introduction to conservation genetics . Cambridge university press.

39. Garcia, K.C., Joshi, H.M. and Dharaiya, N., 2016. Assessment of human-sloth bear conflicts in North Gujarat, India. Ursus, 27 (1), pp.5-10.

40. Garshelis David L., Anup R. Joshi, James L. D. Smith, and Clifford G. Rice. Sloth Bear Conservation Action Plan In Servheen, C., Herrero, S., and Peyton, B. (compilers). (1998) Bears. Status Survey and Conservation Action Plan. IUCN/SSC Bear and Polar Bear Specialist Groups. IUCN, Gland, Switzerland and Cambridge, UK. $\mathrm{x}+309$ pp.

41. Garshelis, D. L., Joshi, A., \& Smith, J. L. D. (1999). Estimating Density and Relative Abundance of Sloth Bears. Urus, 11(1), 87-98.

42. Gaston, K.J., Blackburn, T.M., Greenwood, J.J., Gregory, R.D., Quinn, R.M. and Lawton, J.H., 2000. Abundance-occupancy relationships. Journal of Applied Ecology, 37, pp.39-59.

43. Geldmann, J., Barnes, M., Coad, L., Craigie, I.D., Hockings, M. and Burgess, N.D., 2013. Effectiveness of terrestrial protected areas in reducing habitat loss and population declines. Biological Conservation, 161, pp.230-238.

44. GELDMANN, J., JOPPA, L.N. and BURGESS, N.D. (2014), Mapping Change in Human Pressure Globally on Land and within Protected Areas. Conservation Biology, 28: 16041616. https://doi.org/10.1111/cobi.12332 
45. Geldmann, J., Manica, A., Burgess, N.D., Coad, L. and Balmford, A., 2019. A global-level assessment of the effectiveness of protected areas at resisting anthropogenic pressures. Proceedings of the National Academy of Sciences, 116(46), pp.23209-23215.

46. Ghimire, D. and Thapa, T.B., 2014. Distribution and Habitat Preference of Sloth Bear in Chitwan National Park, Nepal. Journal of Natural History Museum, 28, pp.9-17.

47. Graham, E.B., Averill, C., Bond-Lamberty, B., Knelman, J.E., Krause, S., Peralta, A.L., Shade, A., Smith, A.P., Cheng, S.J., Fanin, N. and Freund, C., 2021. Toward a generalizable framework of disturbance ecology through crowdsourced science. Frontiers in Ecology and Evolution, 9, p.76.

48. Hansen MC, Potapov PV, Moore R, Hancher M, Turubanova SA, Tyukavina A. High-Resolution Global Maps of 21st-Century Forest Cover Change. Science. 2013;342:850-853. pmid:24233722

49. Hines, J.E., 2006. PRESENCE 3.1 Software to estimate patch occupancy and related parameters. http://www. mbr-pwrc. usgs. gov/software/presence. html.

50. Hoffmann, M., Hilton-Taylor, C., Angulo, A., Bohm, M., Brooks, T.M., Butchart, S.H., Carpenter, K.E., Chanson, J., Collen, B., Cox, N.A. and Darwall, W.R., 2010. The impact of conservation on the status of the world's vertebrates. science, 330(6010), pp.1503-1509.

51. Hui, C., McGeoch, M.A., Reyers, B., Roux, P.C., Greve, M. and Chown, S.L., 2009. Extrapolating population size from the occupancy-abundance relationship and the scaling pattern of occupancy. Ecological Applications, 19(8), pp.2038-2048.

52. Islam, M.A., Uddin, M., Aziz, M.A., Muzaffar, S.B., Chakma, S., Chowdhury, S.U., Chowdhury, G.W., Rashid, M.A., Mohsanin, S., Jahan, I. and Saif, S., 2013. Status of bears in Bangladesh: going, going, gone?. Ursus, 24(1), pp.83-90.

53. Iwasaki, A. and Noda, T., 2018. A framework for quantifying the relationship between intensity and severity of impact of disturbance across types of events and species. Scientific reports, 8(1), pp.1-7.

54. Jhala, Y.V., Qureshi, Q. and Nayak, A.K. (eds) 2020. Status of tigers, copredators and prey in India, 2018. National Tiger Conservation Authority, Government of India, New Delhi, and Wildlife Institute of India, Dehradun

55. Jnawali, S.R., H.S. Baral, S. Lee, K.P. Acharya, G.P. Upadhyay, M. Pandey, R. Shrestha, D. Joshi, B.R. Laminchhane, J. Griffiths, A.P. Khatiwada, N. Subedi \& R. Amin (compilers) (2011). The Status of Nepal Mammals. The National Red List Series, Department of National Parks and Wildlife Conservation, Kathmandu, Nepal.

56. Joshi, A. R., Garshelis, D. L., \& Smith, J. L. D. 1997. SEASOnAL AND HABITAT-RELATED DIETS OF SLOTH BEARS IN NEPAL. Journal of Mammalogy, 78(2), 584-597.

57. Joshi, A.R., Garshelis, D.L. and Smith, J.L., 1995. Home ranges of sloth bears in Nepal: Implications for conservation. The Journal of wildlife management, pp.204-214.

58. Joshi, A.R., Smith, J.L. and Garshelis, D.L., 1999. Sociobiology of the myrmecophagous sloth bear in Nepal. Canadian Journal of Zoology, 77 (11), pp.1690-1704.

59. Kafley, H., Lamichhane, B.R., Maharjan, R., Khadka, M., Bhattarai, N. and Gompper, M.E., 2019. Tiger and leopard co-occurrence: intraguild interactions in response to human and livestock disturbance. Basic and Applied Ecology , 40 , pp.78-89.

60. Kalumanga, E., Mpanduji, D.G. and Cousins, S.A., 2017. Geophagic termite mounds as one of the resources for African elephants in Ugalla Game Reserve, Western Tanzania. African journal of ecology , 55 (1), pp.91-100.

61. Karanth, K.U. and Chellam, R., 2009. Carnivore conservation at the crossroads. Oryx , 43 (1), pp.1-2

62. Karki, J.B., Pandav, B., Jnawali, S.R., Shrestha, R., Pradhan, N.M.B., Lamichane, B.R., Khanal, P., Subedi, N. and Jhala, Y.V., 2015. Estimating the abundance of Nepal's largest population of tigers Panthera tigris. Oryx , 49 (1), pp.150-156.

63. Ketting, J., 2020. Social Factors Drive Sloth Bear Conflict In Gujarat: An Integrated Interdisciplinary Approach To Human-Wildlife Conflict And Coexistence (Master's thesis).

64. Khanal, S. and Thapa, T.B., 2014. Feeding ecology of sloth bears in Chitwan National Park, Nepal. Journal of Institute of Science and technology, 19 (2), pp.118-122.

65. Krishna, Y.C., Krishnaswamy, J. and Kumar, N.S., 2008. Habitat factors affecting site occupancy and 
relative abundance of four-horned antelope. Journal of Zoology , 276 (1), pp.63-70.

66. Laing, S.E., Buckland, S.T., Burn, R.W., Lambie, D. and Amphlett, A., 2003. Dung and nest surveys: estimating decay rates. Journal of Applied Ecology , 40 (6), pp.1102-1111.

67. Lamichhane, B.R., Gurung, A., Center, N.B.C., Poudel, S., Pokheral, C.P. and Subedi, N., 2016. Sloth Bear Sightings as a Population Index in Chitwan National Park, Nepal.International Bear News, vol 25,no.1.

68. Lamichhane, B.R., Leirs, H., Persoon, G.A., Subedi, N., Dhakal, M., Oli, B.N., Reynaert, S., Sluydts, V., Pokheral, C.P., Poudyal, L.P. and Malla, S., 2019. Factors associated with co-occurrence of large carnivores in a human-dominated landscape. Biodiversity and Conservation, 28 (6), pp.1473-1491.

69. Lamichhane, B.R., Persoon, G.A., Leirs, H., Musters, C.J.M., Subedi, N., Gairhe, K.P., Pokheral, C.P., Poudel, S., Mishra, R., Dhakal, M. and Smith, J.L.D., 2017. Are conflict-causing tigers different? Another perspective for understanding human-tiger conflict in Chitwan National Park, Nepal. Global ecology and conservation, 11 , pp.177-187.

70. Lamichhane, B.R., Persoon, G.A., Leirs, H., Poudel, S., Subedi, N., Pokheral, C.P., Bhattarai, S., Thapaliya, B.P. and de Iongh, H.H., 2018. Spatio-temporal patterns of attacks on human and economic losses from wildlife in Chitwan National Park, Nepal. PloS one, 13 (4), p.e0195373.

71. Laurie, A. and Seidensticker, J., 1977. Behavioural ecology of the sloth bear (Melursus ursinus). Journal of Zoology, 182 (2), pp.187-204.

72. Lehmkuhl, John F. 1999. The organization and human use of terai riverine grasslands in the Royal Chitwan National Park, Nepal (Vol 2). In: Grassland Ecology and Management in Protected Areas of Nepal: $37-49$

73. Li, S., McShea, W.J., Wang, D. et al (2020). Retreat of large carnivores across the giant panda distribution range. Nat Ecol Evol . https://doi.org/10.1038/s41559-020-1260-0

74. MacKenzie, D.I. and Bailey, L.L., 2004. Assessing the fit of site-occupancy models. Journal of Agricultural, Biological, and Environmental Statistics , 9 (3), pp.300-318.

75. MacKenzie, D.I. and Nichols, J.D., 2004. Occupancy as a surrogate for abundance estimation. Animal biodiversity and conservation, 27 (1), pp.461-467.

76. MacKenzie, D.I. and Royle, J.A., 2005. Designing occupancy studies: general advice and allocating survey effort. Journal of applied Ecology , 42 (6), pp.1105-1114.

77. MacKenzie, D.I., 2003. Assessing site occupancy modelling as a tool for monitoring Mahoenui giant weta populations (p. 17). Department of Conservation.

78. MacKenzie, D.I., Nichols, J.D., Lachman, G.B., Droege, S., Andrew Royle, J. and Langtimm, C.A., 2002. Estimating site occupancy rates when detection probabilities are less than one. Ecology , 83 (8), pp.2248-2255.

79. MacKenzie, D.I., Nichols, J.D., Royle, J.A., Pollock, K.H., Bailey, L. and Hines, J.E., 2017. Occupancy estimation and modeling: inferring patterns and dynamics of species occurrence. Elsevier.

80. MacKenzie, D.I., Royle, J.A., Brown, J.A., Nichols, J.D. and Thompson, W.L., 2004. Occupancy estimation and modeling for rare and elusive populations. Sampling rare or elusive species: concepts, designs, and techniques for estimating population parameters, pp.149-171.

81. Malla, R. and Karki, K., 2016. Groundwater Environment in Chitwan, Nepal. In Groundwater Environment in Asian Cities (pp. 47-75). Butterworth-Heinemann.

82. Maxwell, S., Fuller, R., Brooks, T. et al. Biodiversity: The ravages of guns, nets and bulldozers. Nature 536, 143-145 (2016). https://doi.org/10.1038/536143a

83. Mewada, T.P., 2015. Index of relative importance of the dietary proportions of sloth bear (Melursus ursinus) in semi-arid region. Notulae Scientia Biologicae, 7(3), pp.281-288.

84. Mewada, T.P., Tiwari, U.L. and Kotia, A., 2019. Fruiting Species Influence the Seasonal Use of the Habitat by Sloth Bear in and around Balaram Ambaji Wildlife Sanctuary, Gujarat, India. Notulae Scientia Biologicae, 11(2), pp.183-190.

85. Morin, D.J., Higdon, S.D., Holub, J.L., Montague, D.M., Fies, M.L., Waits, L.P. and Kelly, M.J., 2016. Bias in carnivore diet analysis resulting from misclassification of predator scats based on field identification. Wildlife Society Bulletin, 40(4), pp.669-677. 
86. Mugendi, D.G., 2020. Temporal patterns in Macrotermes mound occupancy in a savanna ecosystem (Master's thesis, Norwegian University of Life Sciences, As).

87. Murphy, S.M., Augustine, B.C., Ulrey, W.A., Guthrie, J.M., Scheick, B.K., McCown, J.W. and Cox, J.J., 2017. Consequences of severe habitat fragmentation on density, genetics, and spatial capturerecapture analysis of a small bear population. PLoS One, 12(7), p.e0181849.

88. Murphy, S.T., Subedi, N., Jnawali, S.R., Lamichhane, B.R., Upadhyay, G.P., Kock, R. and Amin, R., 2013. Invasive mikania in Chitwan National Park, Nepal: the threat to the greater one-horned rhinoceros Rhinoceros unicornis and factors driving the invasion. Oryx, 47(3), pp.361-368.

89. Palei, H.S., Debata, S. and Sahu, H.K., 2020. Diet of sloth bear in an agroforest landscape in eastern India. Agroforestry Systems, 94(1), pp.269-279.

90. Palei, H.S., Mohapatra, P.P. and Sahu, H.K., 2014, June. Dry season diet of the sloth bear (Melursus ursinus) in Hadagarh wildlife sanctuary, Eastern India. In Proceedings of the Zoological Society (Vol. 67, No. 1, pp. 67-71). Springer India.

91. Pant, G., Maraseni, T., Apan, A. and Allen, B.L., 2020. Climate change vulnerability of Asia's most iconic megaherbivore: greater one-horned rhinoceros (Rhinoceros unicornis). Global Ecology and Conservation, 23 , p.e01180.

92. Panthi, S., Khanal, G., Acharya, K.P., Aryal, A. and Srivathsa, A., 2017. Large anthropogenic impacts on a charismatic small carnivore: Insights from distribution surveys of red panda Ailurus fulgens in Nepal. PloS one, 12 (7), p.e0180978.

93. Philip, R., Bhatnagar, C. and Koli, V.K., 2021. Feeding ecology of the vulnerable sloth bear (Melursus ursinus) in and around Mount Abu wildlife sanctuary, Rajasthan, India. International Journal of Environmental Studies, pp.1-11.

94. Pokharel, M. and Aryal, C., 2020. Human-Wildlife Conflict and its Implication for Conservation at Sundarpur, Udayapur, Eastern Nepal. International Journal of Environment, 9 (2), pp.217-233.

95. Pokheral, C.P. and Wegge, P., 2019. Coexisting large carnivores: spatial relationships of tigers and leopards and their prey in a prey-rich area in lowland Nepal. Ecoscience, 26 (1), pp.1-9.

96. Puri, M., Srivathsa, A., Karanth, K. K., Kumar, N. S., \& Karanth, K. U. (2015). Multiscale distribution models for conserving widespread species : the case of sloth bear Melursus ursinus in India. Biodiversity Research, 21(1), 1087-1100. https://doi.org/10.1111/ddi.12335

97. Putman, R.J., 1984. Facts from faeces. Mammal review , 14 (2), pp.79-97.

98. Rajpurohit, K.S. and Krausman, P.R., 2000. Human-sloth-bear conflicts in Madhya Pradesh, India. Wildlife Society Bulletin, pp.393-399.

99. Ramesh, T., Kalle, R., Sankar, K. and Qureshi, Q., 2012. Factors affecting habitat patch use by sloth bears in Mudumalai Tiger Reserve, Western Ghats, India. Ursus, 23(1), pp.78-85.

100. Rather, T.A., Kumar, S. and Khan, J.A., 2021. Using machine learning to predict habitat suitability of sloth bears at multiple spatial scales. Ecological Processes, 10(1), pp.1-12.

101. Rather, T.A., Tajdar, S., Kumar, S. and Khan, J.A., 2020. Seasonal variation in the diet of sloth bears in Bandhavgarh Tiger Reserve, Madhya Pradesh, India. Ursus, 2020(31e12), pp.1-8.

102. Ratnayeke, S., \& Manen, F. T. Van. (2012). Assessing sloth bears as surrogates for carnivore conservation in Sri Lanka. Urus, 23(2), 206-217.

103. Ratnayeke, S., 2021. Sloth Bear: The Barefoot Bear of Sri Lanka. Sunway University Press.

104. Ratnayeke, S., Van Manen, F.T. and Padmalal, U.K.G.K., 2007. Home ranges and habitat use of sloth bears Melursus ursinus inornatus in Wasgomuwa National Park, Sri Lanka. Wildlife Biology, 13(3), pp.272-284.

105. Ratnayeke, S., Van Manen, F.T., Pieris, R. and Pragash, V.S., 2014. Challenges of large carnivore conservation: sloth bear attacks in Sri Lanka. Human Ecology, 42(3), pp.467-479.

106. Ratnayeke, S., Van Manen, F.T., Pieris, R. and Pragash, V.S.J., 2007. Landscape characteristics of sloth bear range in Sri Lanka. Ursus, pp.189-202.

107. Ripple, W. J. et al., 2014. Status and Ecological Effects of the World's Largest Carnivores. Science, 343(6167), p. 1241484

108. Rota, C.T., Fletcher Jr, R.J., Dorazio, R.M. and Betts, M.G., 2009. Occupancy estimation and the 
closure assumption. Journal of Applied Ecology, 46(6), pp.1173-1181.

109. Ruda, A., Kolejka, J. and Silwal, T., 2020. Spatial concentrations of wildlife attacks on humans in Chitwan National Park, Nepal. Animals, 10(1), p.153.

110. S. L. Pimm, C. N. Jenkins, R. Abell, T. M. Brooks, J. L. Gittleman, L. N. Joppa, P. H. Raven, C. M. Roberts, J. O. Sexton. The biodiversity of species and their rates of extinction, distribution, and protection. Science.30 May 2014: Vol. 344, Issue 6187, 1246752 DOI: 10.1126/science.1246752

111. Sacco, T. and Van Valkenburgh, B., 2004. Ecomorphological indicators of feeding behaviour in the bears (Carnivora: Ursidae). Journal of Zoology, 263(1), pp.41-54.

112. Schipper, J., Chanson, J.S., Chiozza, F., Cox, N.A., Hoffmann, M., Katariya, V., Lamoreux, J., Rodrigues, A.S., Stuart, S.N., Temple, H.J. and Baillie, J., 2008. The status of the world's land and marine mammals: diversity, threat, and knowledge. Science, 322(5899), pp.225-230.

113. Schulze, K., Knights, K., Coad, L., Geldmann, J., Leverington, F., Eassom, A., Marr, M., Butchart, S.H., Hockings, M. and Burgess, N.D., 2018. An assessment of threats to terrestrial protected areas. Conservation Letters, 11(3), p.e12435.

114. Sharp, T.R., Swaminathan, S., Arun, A.S., Smith, T., Satyanarayan, K. and Seshamani, G., 2020. Sloth bear attacks on the Deccan Plateau of Karnataka, India. Ursus, 2020(31e8), pp.1-11.

115. Silwal, T., 2019. Human-wildlife conflict: Analysis of factors involved in wildlife attacks on humans in and around Chitwan National Park, Nepal (Doctoral dissertation).

116. Singh Chakraborty, J. and Singh, S., 2020. Abundance, population density and spatial ecology of mound-building termites in moist tropical deciduous forests of northern India. Ecoscience, 27(3), pp.209-222.

117. Smith, J.L.D., 1984. Dispersal, communication, and conservation strategies for the tiger (Panthera tigris) in Royal Chitwan National Park, Nepal (Doctoral dissertation, University of Minnesota).

118. Soizic Le Saout, Michael Hoffmann, Yichuan Shi, Adrian Hughes, Cyril Bernard, Thomas M. Brooks, Bastian Bertzky, Stuart H. M. Butchart, Simon N. Stuart, Tim Badman, Ana S. L. Rodrigues. Protected Areas and Effective Biodiversity Conservation. Science 15 Nov 2013. Vol. 342, Issue 6160, pp. 803-805 DOI: 10.1126/science.1239268

119. Sousa Wayne P. 1984. Annual Review of Ecology and Systematics. Vol. 15 (1984), pp. 353-391 (39 pages). Annual Reviews Inc. https://www.jstor.org/stable/2096953

120. Sreekumar, P.G. and Balakrishnan, M., 2002. Seed Dispersal by the Sloth Bear (Melursus ursinus) in South India1. Biotropica, 34(3), pp.474-477.

121. Subedi, N., Lamichhane, B.R., Amin, R., Jnawali, S.R. and Jhala, Y.V., 2017. Demography and viability of the largest population of greater one-horned rhinoceros in Nepal. Global Ecology and Conservation, 12, pp.241-252.

122. Subedi, N., Lamichhane, B.R., Dahal, Y.N., Kandel, R.C., Karki Thapa, M., Regmi, R. and Shrestha, B., 2021. Tigers in Himalayan foothills: Possible linkage between two Tiger population clusters in Terai Arc Landscape, Nepal. Journal of Animal Diversity, 3(2), pp.0-0.

123. Sukhadiya, D., Joshi, J.U. and Dharaiya, N., 2013. Feeding Ecology and Habitat Use of Sloth Bear (Melursus ursinus) in Jassore Wildlife Sanctuary, Gujarat, India. Ind J Ecol, 40(1), pp.14-18.

124. Thapa, K. and Kelly, M.J., 2017. Prey and tigers on the forgotten trail: high prey occupancy and tiger habitat use reveal the importance of the understudied Churia habitat of Nepal. Biodiversity and Conservation, 26(3), pp.593-616.

125. Thapa, K., Malla, S., Subba, S.A., Thapa, G.J., Lamichhane, B.R., Subedi, N., Dhakal, M., Acharya, K.P., Thapa, M.K., Neupane, P. and Poudel, S., 2021. On the tiger trails: Leopard occupancy decline and leopard interaction with tigers in the forested habitat across the Terai Arc Landscape of Nepal. Global Ecology and Conservation, 25, p.e01412.

126. Thatte, P., Chandramouli, A., Tyagi, A., Patel, K., Baro, P., Chhattani, H. and Ramakrishnan, U., 2020. Human footprint differentially impacts genetic connectivity of four wide-ranging mammals in a fragmented landscape. Diversity and Distributions, 26(3), pp.299-314.

127. Thomas CD, Cameron A, Green RE, Bakkenes M, Beaumont LJ, Collingham YC, Erasmus BF, De Siqueira MF, Grainger A, Hannah L, Hughes L, Huntley B, Van Jaarsveld AS, Midgley GF, Miles 
L, Ortega-Huerta MA, Peterson AT, Phillips OL, Williams SE. Extinction risk from climate change. Nature. 2004 Jan 8;427(6970):145-8. doi: 10.1038/nature02121. PMID: 14712274.

128. UNEP-WCMC and IUCN (2021) Protected Planet Report 2020. UNEP-WCMC and IUCN: Cambridge UK; Gland, Switzerland.

129. Wilson, M.C., Chen, X.Y., Corlett, R.T., Didham, R.K., Ding, P., Holt, R.D., Holyoak, M., Hu, G., Hughes, A.C., Jiang, L. and Laurance, W.F., 2016. Habitat fragmentation and biodiversity conservation: key findings and future challenges.

130. Yoganand, K., Rice, C.G. and Johnsingh, A.J.T., 2005. Evaluating Panna National Park with special reference to ecology of sloth bear (Melursus ursinus). Final project report. Wildlife Institute of India, Dehradun, India.

131. Zuckerberg, B., Porter, W.F. and Corwin, K., 2009. The consistency and stability of abundanceoccupancy relationships in large-scale population dynamics. Journal of Animal Ecology, 78(1), pp.172181.

Table 1. Description of covariates and hypothesized response on occupancy(Psi) and detection (P) of sloth bear. ' +' signifies a positive effect on the response variable, '-' signifies a negative effect on the response variable and '*' signifies that the covariate has no effect on the response variable.

\begin{tabular}{|c|c|c|c|}
\hline Covariate & Description & Psi & $\mathbf{P}$ \\
\hline $\begin{array}{l}\text { Enhanced Vegetation } \\
\text { Index (EVI) }\end{array}$ & $\begin{array}{l}\text { EVI (2018) was obtained } \\
\text { from SRTM vegetation } \\
\text { index available at } \\
\text { https://earthexplorer.usgs.g }\end{array}$ & ov. & $*$ \\
\hline Tree Cover (TC) & $\begin{array}{l}\text { Prepared by Hansen et } \\
\text { al. 2013, downloaded } \\
\text { from the Global Forest } \\
\text { Change website. } \\
\text { (http://earthenginepartners } \\
\text { 2013-global-forest). }\end{array}$ & .appspot.com/science- & $*$ \\
\hline $\begin{array}{l}\text { Terrain Ruggedness } \\
\text { Index (TRI) }\end{array}$ & $\begin{array}{l}\text { Calculated in ArcGIS } \\
\text { using } 30 \mathrm{~m} \text { resolution } \\
\text { Digital Elevation Model } \\
\text { (DEM) layer from the } \\
\text { U.S. Geological Survey } \\
\text { (USGS) website } \\
\text { (https://earthexplorer.usgs. }\end{array}$ & $\operatorname{gov} /)$ & $*$ \\
\hline Disturbance (D) & $\begin{array}{l}\text { Presence absence } \\
(\mathrm{P} / \mathrm{A}) \text { score of human, } \\
\text { livestock and fire } \\
\text { disturbance recorded in } \\
\text { field and pooled to } \\
\text { obtain an average score } \\
\text { for each grid. }\end{array}$ & - & - \\
\hline Fruit (F) & $\begin{array}{l}\text { Presence absence of fruit } \\
\text { plants most frequently } \\
\text { consumed during the dry } \\
\text { season in Chitwan } \\
\text { (Khanal \& Thapa, } 2014 \\
\text { was pooled to obtain an } \\
\text { average fruit score for } \\
\text { each grid. }\end{array}$ & + & + \\
\hline
\end{tabular}




\begin{tabular}{llll}
\hline Covariate & Description & Psi & P \\
\hline Termite (T) & Presence absence of & + & + \\
& termites recorded in field & & \\
& and single score for each & & \\
& grid obtained by & & \\
& averaging scores across & & \\
& four replicates. & \\
\hline
\end{tabular}

Table 2. Summary of model selection process (Step 1) for factors affecting detection probability of Sloth bear

\begin{tabular}{llllll}
\hline Model & AIC & $\boldsymbol{\Delta} \mathbf{A I}^{\mathbf{n}}$ & $\mathbf{W}_{\boldsymbol{i}}$ & $\mathbf{M L}$ & $\mathbf{K}$ \\
\hline $\mathrm{psi}(),. \mathrm{p}(\mathrm{T}+\mathrm{F}+\mathrm{D})$ & 161.81 & 0.00 & 0.54 & 1.00 & 5.00 \\
$\operatorname{psi}(),. \mathrm{p}(\mathrm{T}+\mathrm{F})$ & 163.22 & 1.41 & 0.27 & 0.49 & 4.00 \\
$\operatorname{psi}(),. \mathrm{p}(\mathrm{T}+\mathrm{D})$ & 164.42 & 2.61 & 0.15 & 0.27 & 4.00 \\
$\operatorname{psi}(),. \mathrm{p}(\mathrm{T})$ & 167.27 & 5.46 & 0.04 & 0.07 & 3.00 \\
$\operatorname{psi}(),. \mathrm{p}(\mathrm{F}+\mathrm{D})$ & 171.00 & 9.19 & 0.01 & 0.01 & 4.00 \\
$\operatorname{psi}(),. \mathrm{p}(\mathrm{D})$ & 171.12 & 9.31 & 0.01 & 0.01 & 3.00 \\
$\operatorname{psi}(),. \mathrm{p}(\mathrm{F})$ & 174.12 & 12.31 & 0.00 & 0.00 & 3.00 \\
$\operatorname{psi}(),. \mathrm{p}()$. & 175.48 & 13.67 & 0.00 & 0.00 & 2.00 \\
\hline
\end{tabular}

AIC- Akaike's information criterion, $\triangle$ AIC- difference in the AIC values between each model and the model with the lowest AIC, $\mathrm{W}_{i-}$ AIC model weight, K- Number of parameters estimated by the model, T-Termite, F- Fruit D- Disturbance

Table 3. Summary of model selection process (Step 2) for Sloth bear occupancy . Coefficient of variation was used for TRI, EVI and the disturbance index was developed using resource collection, fire and grazing

\begin{tabular}{|c|c|c|c|c|c|}
\hline Model & AIC & $\Delta \mathrm{AIC}$ & $\mathrm{Wi}$ & ML & $\mathrm{K}$ \\
\hline $\mathrm{psi}(\mathrm{T}+\mathrm{F}), \mathrm{p}(\mathrm{T}+\mathrm{F}+\mathrm{D})$ & 159.02 & 0.00 & 0.12 & 1.00 & 7.00 \\
\hline $\operatorname{psi}(\mathrm{T}), \mathrm{p}(\mathrm{T}+\mathrm{F}+\mathrm{D})$ & 159.06 & 0.04 & 0.12 & 0.98 & 6.00 \\
\hline $\operatorname{psi}(\mathrm{T}+\mathrm{F}+\mathrm{D}), \mathrm{p}(\mathrm{T}+\mathrm{F}+\mathrm{D})$ & 159.28 & 0.26 & 0.11 & 0.88 & 8.00 \\
\hline $\mathrm{psi}(\mathrm{T}+\mathrm{D}), \mathrm{p}(\mathrm{T}+\mathrm{F}+\mathrm{D})$ & 160.11 & 1.09 & 0.07 & 0.58 & 7.00 \\
\hline $\mathrm{psi}(\mathrm{T}+\mathrm{TC}), \mathrm{p}(\mathrm{T}+\mathrm{F}+\mathrm{D})$ & 160.20 & 1.18 & 0.07 & 0.55 & 7.00 \\
\hline $\mathrm{psi}(\mathrm{T}+\mathrm{F}+\mathrm{TRI}), \mathrm{p}(\mathrm{T}+\mathrm{F}+\mathrm{D})$ & 160.47 & 1.45 & 0.06 & 0.48 & 8.00 \\
\hline $\mathrm{psi}(\mathrm{T}+\mathrm{F}+\mathrm{TC}), \mathrm{p}(\mathrm{T}+\mathrm{F}+\mathrm{D})$ & 160.49 & 1.47 & 0.06 & 0.48 & 8.00 \\
\hline $\mathrm{psi}(\mathrm{T}+\mathrm{F}+\mathrm{EVI}), \mathrm{p}(\mathrm{T}+\mathrm{F}+\mathrm{D})$ & 160.58 & 1.56 & 0.06 & 0.46 & 8.00 \\
\hline $\operatorname{psi}(\mathrm{TC}+\mathrm{T}+\mathrm{F}+\mathrm{D}), \mathrm{p}(\mathrm{T}+\mathrm{F}+\mathrm{D})$ & 161.28 & 2.26 & 0.04 & 0.32 & 9.00 \\
\hline $\mathrm{psi}(\mathrm{F}), \mathrm{p}(\mathrm{T}+\mathrm{F}+\mathrm{D})$ & 161.58 & 2.56 & 0.03 & 0.28 & 6.00 \\
\hline $\operatorname{psi}(),. \mathrm{p}(\mathrm{T}+\mathrm{F}+\mathrm{D})$ & 161.81 & 2.79 & 0.03 & 0.25 & 5.00 \\
\hline $\mathrm{psi}(\mathrm{TC}+\mathrm{D}+\mathrm{T}), \mathrm{p}(\mathrm{T}+\mathrm{F}+\mathrm{D})$ & 161.89 & 2.87 & 0.03 & 0.24 & 8.00 \\
\hline $\operatorname{psi}(\mathrm{TC}+\mathrm{T}+\mathrm{F}+\mathrm{TRI}), \mathrm{p}(\mathrm{T}+\mathrm{F}+\mathrm{D})$ & 162.05 & 3.03 & 0.03 & 0.22 & 9.00 \\
\hline $\operatorname{psi}(\mathrm{F}+\mathrm{D}), \mathrm{p}(\mathrm{T}+\mathrm{F}+\mathrm{D})$ & 162.22 & 3.20 & 0.02 & 0.20 & 7.00 \\
\hline $\mathrm{psi}(\mathrm{TC}+\mathrm{T}+\mathrm{F}+\mathrm{EVI}), \mathrm{p}(\mathrm{T}+\mathrm{F}+\mathrm{D})$ & 162.37 & 3.35 & 0.02 & 0.19 & 9.00 \\
\hline $\operatorname{psi}(\mathrm{TRI}), \mathrm{p}(\mathrm{T}+\mathrm{F}+\mathrm{D})$ & 162.93 & 3.91 & 0.02 & 0.14 & 6.00 \\
\hline $\operatorname{psi}(\mathrm{EVI}), \mathrm{p}(\mathrm{T}+\mathrm{F}+\mathrm{D})$ & 162.94 & 3.92 & 0.02 & 0.14 & 6.00 \\
\hline $\operatorname{psi}(\mathrm{TC}), \mathrm{p}(\mathrm{T}+\mathrm{F}+\mathrm{D})$ & 163.03 & 4.01 & 0.02 & 0.13 & 6.00 \\
\hline $\operatorname{psi}(\mathrm{D}), \mathrm{p}(\mathrm{T}+\mathrm{F}+\mathrm{D})$ & 163.15 & 4.13 & 0.02 & 0.13 & 6.00 \\
\hline $\mathrm{psi}(\mathrm{F}+\mathrm{TC}), \mathrm{p}(\mathrm{T}+\mathrm{F}+\mathrm{D})$ & 163.40 & 4.38 & 0.01 & 0.11 & 7.00 \\
\hline
\end{tabular}




\begin{tabular}{|c|c|c|c|c|c|}
\hline Model & $\mathrm{AIC}$ & $\Delta \mathrm{AIC}$ & Wi & ML & $\mathrm{K}$ \\
\hline $\mathrm{psi}(\mathrm{TC}+\mathrm{TRI}+\mathrm{EVI}+\mathrm{T}), \mathrm{p}(\mathrm{T}+\mathrm{F}+\mathrm{D})$ & 163.88 & 4.86 & 0.01 & 0.09 & 9.00 \\
\hline $\mathrm{psi}(\mathrm{TC}+\mathrm{TRI}), \mathrm{p}(\mathrm{T}+\mathrm{F}+\mathrm{D})$ & 164.12 & 5.10 & 0.01 & 0.08 & 7.00 \\
\hline $\operatorname{psi}(\mathrm{TC}+\mathrm{D}+\mathrm{F}), \mathrm{p}(\mathrm{T}+\mathrm{F}+\mathrm{D})$ & 164.20 & 5.18 & 0.01 & 0.08 & 8.00 \\
\hline $\mathrm{psi}(\mathrm{TC}+\mathrm{EVI}), \mathrm{p}(\mathrm{T}+\mathrm{F}+\mathrm{D})$ & 164.57 & 5.55 & 0.01 & 0.06 & 7.00 \\
\hline $\operatorname{psi}(\mathrm{TC}+\mathrm{D}), \mathrm{p}(\mathrm{T}+\mathrm{F}+\mathrm{D})$ & 164.75 & 5.73 & 0.01 & 0.06 & 7.00 \\
\hline $\mathrm{psi}(\mathrm{TC}+\mathrm{TRI}+\mathrm{EVI}+\mathrm{T}+\mathrm{F}+\mathrm{D}), \mathrm{p}(\mathrm{T}+\mathrm{F}+\mathrm{D})$ & 164.96 & 5.94 & 0.01 & 0.05 & 11.00 \\
\hline $\mathrm{psi}(\mathrm{TC}+\mathrm{TRI}+\mathrm{EVI}), \mathrm{p}(\mathrm{T}+\mathrm{F}+\mathrm{D})$ & 165.87 & 6.85 & 0.00 & 0.03 & 8.00 \\
\hline $\mathrm{psi}(\mathrm{TC}+\mathrm{TRI}+\mathrm{EVI}+\mathrm{F}), \mathrm{p}(\mathrm{T}+\mathrm{F}+\mathrm{D})$ & 166.23 & 7.21 & 0.00 & 0.03 & 9.00 \\
\hline $\operatorname{psi}(),. p()$. & 175.48 & 16.46 & 0.00 & 0.00 & 2.00 \\
\hline
\end{tabular}

AIC- Akaike's information criterion, $\triangle$ AIC- difference in the AIC values between each model and the model with the lowest AIC, $\mathrm{W}_{i \text { - }}$ AIC model weight, K- Number of parameters estimated by the model, T-Termite, F- Fruit plants, D- Disturbance Index, TC-Tree Cover, EVI-Enhanced Vegetation Index, TRITerrain Ruggedness Index

Table 4: Comparison of occupancy and detection estimates, top occupancy model, associated covariates, and their influence on sloth bear occupancy.

\begin{tabular}{lllll}
\hline Author & Study Area & Psi & P & Best Model \& influence of covariates \\
\hline This Study & Nepal- Chitwan National Park & 0.53 & 0.44 & Termite (+) \& Fruit $(+)$ \\
Srivathsa et.al 2017 & India- Bhadra Tiger Reserve & 0.57 & 0.39 & NDVI (-); Forest cover $(+)$ \& Ruggedness $(+)$ \\
Puri et.al 2015 & India & 0.61 & 0.40 & Forest cover (+) Ruggedness (+) Mean annual prec \\
Babu et.al 2015 & India- Meghamalai Hills & 0.54 & 0.33 & Grass cover (+), Tree height (+) \& Disturbance (-) \\
Das et.al 2014 & India- Northeastern Karnataka & 0.79 & 0.47 & Termite (+) \& Fruit Trees (+) \\
Ramesh et al 2012 & India- Mudumalai Tiger Reserve & 0.83 & 0.23 & Null model \\
Ratnayeke et.al 2007 & Srilanka & 0.48 & NA & Monsoon forest $(+)$, Road density (-), Elevation (-) \\
\hline
\end{tabular}

Appendix 1 : Combined list of occupancy and detection models ranked according to AIC

\begin{tabular}{|c|c|c|c|c|c|}
\hline Model & $\mathrm{AIC}$ & $\Delta \mathrm{AIC}$ & $\mathrm{Wi}$ & ML & $\mathrm{K}$ \\
\hline$p s i(T+F), p(T+F+D)$ & 159.02 & 0.00 & 0.12 & 1.00 & 7.00 \\
\hline $\mathrm{psi}(\mathrm{T}), \mathrm{p}(\mathrm{T}+\mathrm{F}+\mathrm{D})$ & 159.06 & 0.04 & 0.12 & 0.98 & 6.00 \\
\hline $\mathrm{psi}(\mathrm{T}+\mathrm{F}+\mathrm{D}), \mathrm{p}(\mathrm{T}+\mathrm{F}+\mathrm{D})$ & 159.28 & 0.26 & 0.10 & 0.88 & 8.00 \\
\hline $\mathrm{psi}(\mathrm{T}+\mathrm{D}), \mathrm{p}(\mathrm{T}+\mathrm{F}+\mathrm{D})$ & 160.11 & 1.09 & 0.07 & 0.58 & 7.00 \\
\hline $\mathrm{psi}(\mathrm{T}+\mathrm{TC}), \mathrm{p}(\mathrm{T}+\mathrm{F}+\mathrm{D})$ & 160.20 & 1.18 & 0.07 & 0.55 & 7.00 \\
\hline $\mathrm{psi}(\mathrm{T}+\mathrm{F}+\mathrm{TRI}), \mathrm{p}(\mathrm{T}+\mathrm{F}+\mathrm{D})$ & 160.47 & 1.45 & 0.06 & 0.48 & 8.00 \\
\hline $\mathrm{psi}(\mathrm{T}+\mathrm{F}+\mathrm{TC}), \mathrm{p}(\mathrm{T}+\mathrm{F}+\mathrm{D})$ & 160.49 & 1.47 & 0.06 & 0.48 & 8.00 \\
\hline $\mathrm{psi}(\mathrm{T}+\mathrm{F}+\mathrm{EVI}), \mathrm{p}(\mathrm{T}+\mathrm{F}+\mathrm{D})$ & 160.58 & 1.56 & 0.05 & 0.46 & 8.00 \\
\hline $\mathrm{psi}(\mathrm{TC}+\mathrm{T}+\mathrm{F}+\mathrm{DI}), \mathrm{p}(\mathrm{T}+\mathrm{F}+\mathrm{D})$ & 161.28 & 2.26 & 0.04 & 0.32 & 9.00 \\
\hline $\mathrm{psi}(\mathrm{F}), \mathrm{p}(\mathrm{T}+\mathrm{F}+\mathrm{D})$ & 161.58 & 2.56 & 0.03 & 0.28 & 6.00 \\
\hline $\operatorname{psi}(),. \mathrm{p}(\mathrm{T}+\mathrm{F}+\mathrm{D})$ & 161.81 & 2.79 & 0.03 & 0.25 & 5.00 \\
\hline $\operatorname{psi}(\mathrm{TC}+\mathrm{D}+\mathrm{T}), \mathrm{p}(\mathrm{T}+\mathrm{F}+\mathrm{D})$ & 161.89 & 2.87 & 0.03 & 0.24 & 8.00 \\
\hline $\mathrm{psi}(\mathrm{TC}+\mathrm{T}+\mathrm{F}+\mathrm{TRI}), \mathrm{p}(\mathrm{T}+\mathrm{F}+\mathrm{D})$ & 162.05 & 3.03 & 0.03 & 0.22 & 9.00 \\
\hline $\operatorname{psi}(\mathrm{F}+\mathrm{D}), \mathrm{p}(\mathrm{T}+\mathrm{F}+\mathrm{D})$ & 162.22 & 3.20 & 0.02 & 0.20 & 7.00 \\
\hline $\mathrm{psi}(\mathrm{TC}+\mathrm{T}+\mathrm{F}+\mathrm{EVI}), \mathrm{p} \mathrm{p}(\mathrm{T}+\mathrm{F}+\mathrm{D})$ & 162.37 & 3.35 & 0.02 & 0.19 & 9.00 \\
\hline $\mathrm{psi}(\mathrm{TRI}), \mathrm{p}(\mathrm{T}+\mathrm{F}+\mathrm{D})$ & 162.93 & 3.91 & 0.02 & 0.14 & 6.00 \\
\hline $\mathrm{psi}(\mathrm{EVI}), \mathrm{p}(\mathrm{T}+\mathrm{F}+\mathrm{D})$ & 162.94 & 3.92 & 0.02 & 0.14 & 6.00 \\
\hline $\mathrm{psi}(\mathrm{TC}), \mathrm{p}(\mathrm{T}+\mathrm{F}+\mathrm{D})$ & 163.03 & 4.01 & 0.02 & 0.13 & 6.00 \\
\hline
\end{tabular}




\begin{tabular}{llllll}
\hline Model & AIC & $\Delta$ AIC & Wi & ML & K \\
\hline psi(D), p(T+F+D) & 163.15 & 4.13 & 0.02 & 0.13 & 6.00 \\
psi(.),p(T+F+D) & 163.22 & 4.20 & 0.01 & 0.12 & 4.00 \\
psi(F+TC), p(T+F+D) & 163.40 & 4.38 & 0.01 & 0.11 & 7.00 \\
psi(TC+TRI+EVI+T), p(T+F+D) & 163.88 & 4.86 & 0.01 & 0.09 & 9.00 \\
psi(TC+TRI),p p(T+F+D) & 164.12 & 5.10 & 0.01 & 0.08 & 7.00 \\
psi(TC+D+F), p(T+F+D) & 164.20 & 5.18 & 0.01 & 0.08 & 8.00 \\
psi(.),p(T+D) & 164.42 & 5.40 & 0.01 & 0.07 & 4.00 \\
psi(TC+EVI), p(T+F+D) & 164.57 & 5.55 & 0.01 & 0.06 & 7.00 \\
psi(TC+D), p(T+F+D) & 164.75 & 5.73 & 0.01 & 0.06 & 7.00 \\
psi(TC+TRI+EVI+T+F+D),p(T+F+D) & 164.96 & 5.94 & 0.01 & 0.05 & 11.00 \\
psi(TC+TRI+EVI),p p(T+F+D) & 165.87 & 6.85 & 0.00 & 0.03 & 8.00 \\
psi(TC+TRI+EVI+F), p(T+F+D) & 166.23 & 7.21 & 0.00 & 0.03 & 9.00 \\
psi(.),p(T) & 167.27 & 8.25 & 0.00 & 0.02 & 3.00 \\
psi(.),p(F+D) & 171.00 & 11.98 & 0.00 & 0.00 & 4.00 \\
psi(.),p(D) & 171.12 & 12.10 & 0.00 & 0.00 & 3.00 \\
psi(.),p(F) & 174.12 & 15.10 & 0.00 & 0.00 & 3.00 \\
psi(.),p(.) & 175.48 & 16.46 & 0.00 & 0.00 & 2.00 \\
\hline
\end{tabular}

Appendix 2: Covariates influencing Sloth bear occupancy inferred from top model $(\Delta \mathrm{AIC}<2)$, ranked on the basis of summed model weights with averaged $\beta$ co-efficients and associated standard error.

\begin{tabular}{lllllll}
\hline Estimate & Variable & AIC_Weight & Beta & SE & LCI & UCI \\
\hline Occupancy & T & 0.66 & 0.84 & 0.41 & 0.03 & 1.65 \\
& F & 0.40 & 0.62 & 0.44 & -0.25 & 1.48 \\
& D & 0.18 & 0.61 & 0.55 & -0.47 & 1.69 \\
& TRI & 0.06 & 0.28 & 0.41 & -0.52 & 1.09 \\
& EVI & 0.06 & 0.25 & 0.38 & -0.50 & 0.99 \\
& TC & 0.13 & -0.33 & 0.41 & -1.14 & 0.48 \\
Detection & T & 0.81 & 1.80 & 0.53 & 0.76 & 2.83 \\
& F & 0.53 & 0.88 & 0.39 & 0.12 & 1.65 \\
& D & 0.70 & -0.59 & 0.33 & -1.22 & 0.05 \\
\hline
\end{tabular}



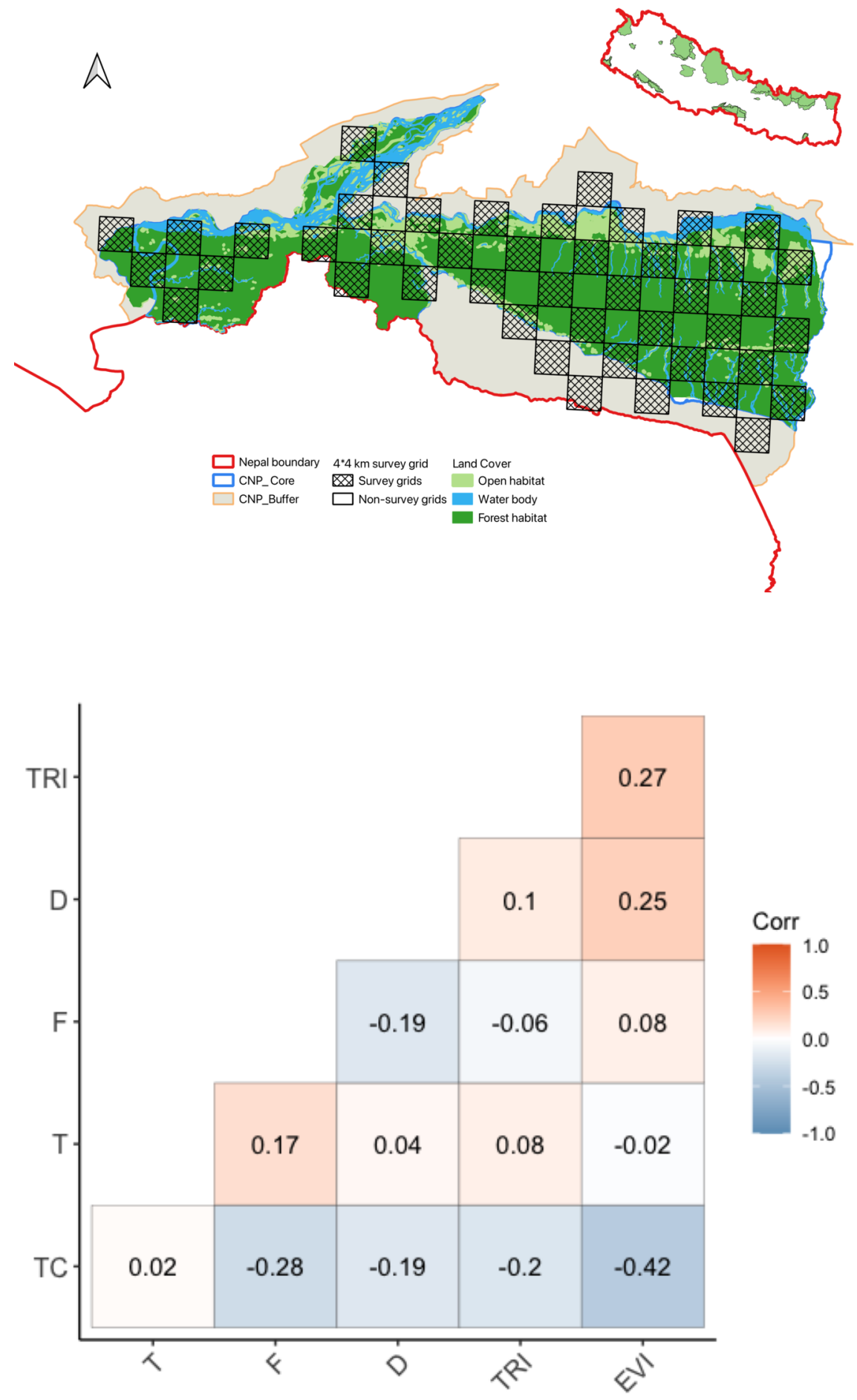


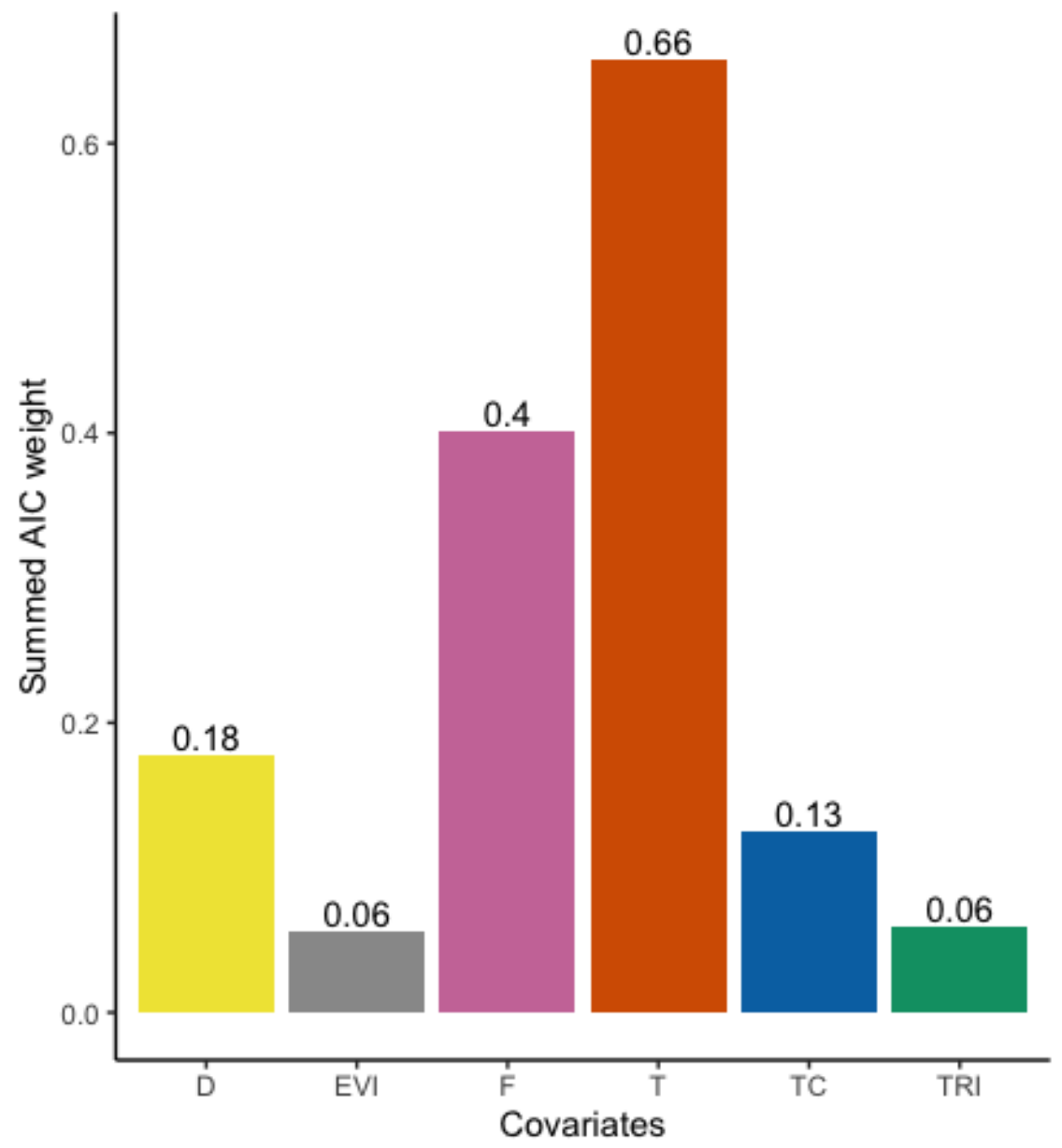



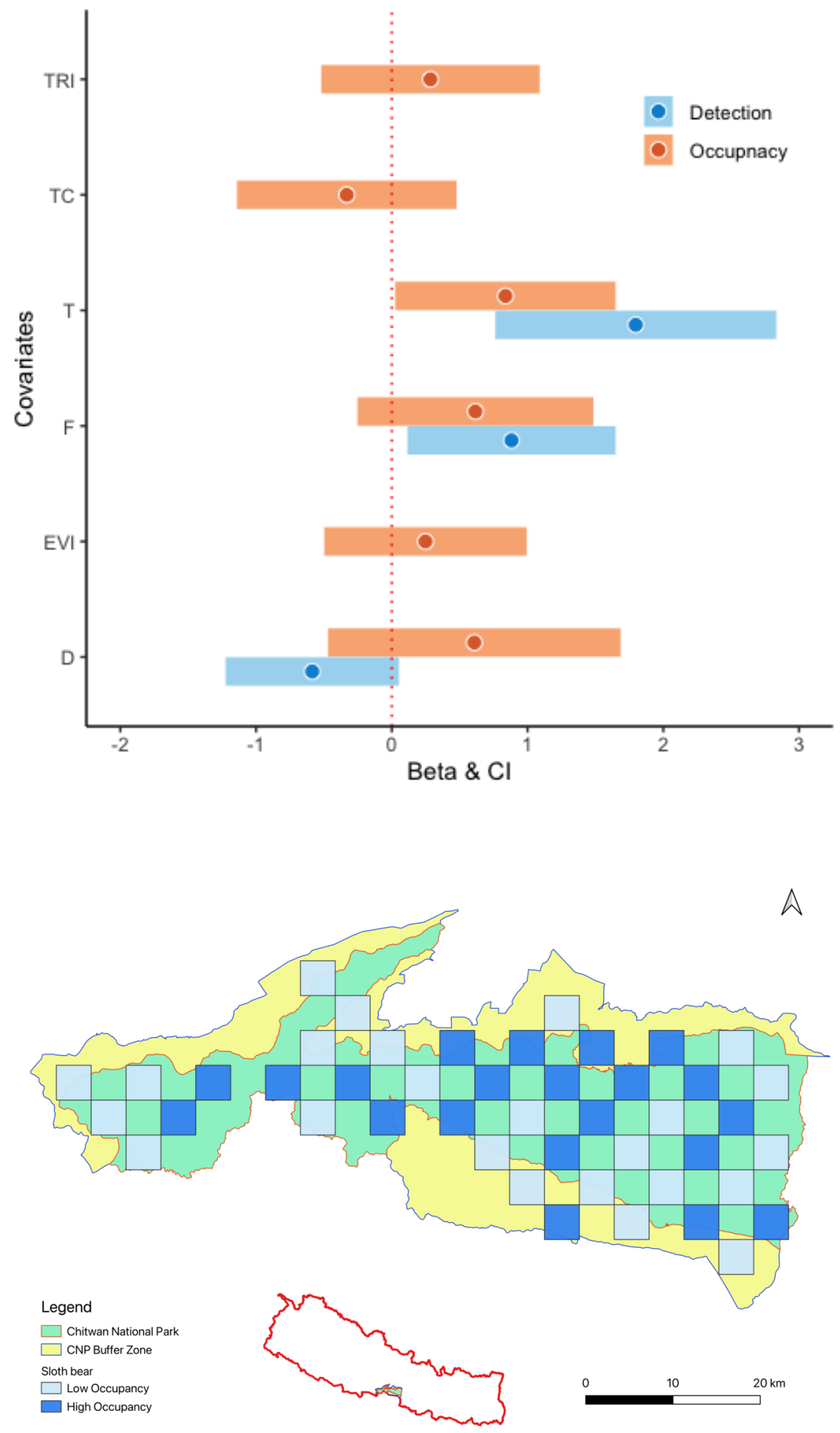